\title{
HUBUNGAN PENGUASAAN KONSEP FISIKA DAN BIOLOGI DENGAN KONTEKS SIKLUS AIR BERDASARKAN CAPAIAN PENGUASAAN KONSEP DAN KEMAMPUAN MENGIDENTIFIKASI MASALAH DI LAPANGAN
}

\author{
Tirsa Mumek, Christophil Medellu, Djeli Alvi Tulandi \\ Fakultas Matematika dan Ilmu Pengetahuan Alam, Universitas Negeri Manado \\ email: tirsamumek@yahoo.co.id
}

\begin{abstract}
ABSTRAK
Memanfaatkan lingkungan sekitar sebagai sumber pelajaran dan mengaitkan dengan pelajaran yang di pelajari siswa di sekolah masih jarang dilakukan dewasa ini, sehingga membuat siswa kurang memahami hubungan konteks dengan konsep. Tujuan dari penelitian ini adalah untuk mendeskripsikan hubungan konteks siklus air dengan konsep fisika dengan konsep matapelajaran lain berdasarkan capaian penguasaan konsep dan kemampuan mengidentifikasi masalah dilapangan. Hasil penelitian menunjukkan korelasi antara penguasaan konsep fisika perubahan wujud zat dengan konsep biologi evapotranspirasi dari 8 siswa adalah 0,59 , hasil korelasi observasi lapangan mengidentifikasi limbah (padat dan cair) di sungai dengan teknologi pengolahan limbah dan bentuk pengendalian pencemaran air adalah 1, dan korelasi konsep skema siklus air dan komponen-komponennya dengan kemampuan siswa mengidentifikasi sumber-sumber air di desa, desa tetangga dan di tempat lain adalah 0,89 .
\end{abstract}

Kata kunci: Siklus air, Pendekatan konteks konsep

\begin{abstract}
Utilizing the surrounding environment as source of lessons and relate them with the lessons that studied by the student in school are still rarely done nowadays, which make the students not really understand the relation of context and concept. The purpose of this study is to describe the relation between water cycle context with physics concept and other subject base on the result of concept mastery and the ability to identify the problems in the field. The results showed that the correlation between the physics mastery of phase transition with biology concept of evapotranspiration of 8 students is 0.59 , the correlation between observations in field to identify the sewage (solid and liquid) on the river with the sewage treatment technology and water pollution control is 1, and correlation between water cycle concept charts and its components with the students ability to identified water sources in the village, neighbourhood and in other places is 0,89 .
\end{abstract}

Keywords: Water cycle, Context concept approach 


\section{PENDAHULUAN}

Air memiliki peran yang sangat penting dalam kehidupan manusia, sebagaimana dituliskan Mitchell (1945) bahwa sebagian besar tubuh manusia terdiri dari air. Selain itu, manusia juga membutuhkan air untuk kegiatan sehari-hari seperti: mandi, memasak, mencuci, pertanian, peternakan, pembangkit tenaga listrik dan masih banyak lagi.

Air memiliki tiga bentuk yaitu gas yang kita sebut dengan uap, cair yang kita sebut dengan air, dan padat atau yang kita sebut dengan es. Menurut United States Geological Survey (2013), pergerakan air yang terus menerus dipermukaan bumi, di atmosfir dan di dalam tanah disebut siklus air.

Melayu (2014), menulis bahwa pembelajaran tematik merupakan salah satu model pembelajaran terpadu yang menggunakan tema untuk mengaitkan beberapa mata pelajaran sehingga dapat memberikan pengalaman bermakna bagi peserta didik. Selanjutnya beliau menambahkan dalam artikelnya, peserta didik membentuk pengetahuannya melalui interaksi dengan lingkungan, bukan hasil bentukan orang lain. Proses pembentukan pengetahuan tersebut berlangsung secara terus menerus sehingga pengetahuan yang dimiliki peserta didik menjadi semakin lengkap. Sebelumnya Anonymous dikutip oleh Medellu (2013) mengemukakan tujuan instruksi tematik yaitu memilih tema yang berhubungan dengan kehidupan siswa dan menjamin siswa memberi perhatian dan menyenangi konten pembelajaran.

Komponen dasar dari metode ini menurut Anonymous yang dikutip oleh Medellu (2013) adalah: memilih sebuah tema, menentukan kerangka waktu (time frame), selanjutnya instruktur melakukan penelitian yang lebih lengkap, menyiapkan segala sesuatu yang akan dibutuhkan siswa ketika turun lapangan, sehingga ketika siswa turun lapangan mereka bisa mulai memproses informasi yang akan terserap lebih baik jika siswa di bagi dalam kelompok. Setelah itu siswa dipecah dari kelompok untuk bekerja sendiri. Pada tingkat ini, siswa mengubah data penelitian ke konsep mereka sendiri, yang kita sebut gagasan besar.

Medellu (2013) membahas karakteristik materi yang dibahas dalam tugas tematik yaitu: materi tugas tematik meliputi komponen kontekstual dan konseptual dari berbagai bidang ilmu atau matapelajaran yang terkait dalam satu tema. Komponen kontekstual materi tugas tematik dapat berupa fakta dan fenomena fisik di sekitar siswa, fenomena fisik global yang berkaitan dengan fenomena lokal, isuisu sosial di lingkungan sekitar dan isu-isu global yang berkaitan dengan isu-isu lokal, nilai-nilai budaya dalam masyarakat, perilaku masyarakat dan dampak terhadap pemanfaatan sumberdaya, program pemerintah dan respons masyarakat. Komponen-komponen materi ini dirancang dalam satu atau beberapa tahapan kegiatan tapi terintegrasi atau satu sama lain. Keluasan dan kedalaman materi tugas tematik disesuaikan dengan kedalaman konsep-konsep terkait dalam masingmasing matapelajaran, sesuai dengan jenjang pendidikan dan usia siswa. Rancangan instruksi tematik bisa membantu menumbuhkan insiatif-insiatif belajar karena siswa saling memotivasi untuk menjawab instruksi maupun untuk membangun pengalaman dan pemahaman terhadap fenomena alam atau isu-isu sosial yang menarik. Rancangan instruksi tematik seperti ini, berpotensi mendorong siswa untuk memanfaatkan waktu di luar sekolah secara maksimal untuk kegiatan belajar.

Siswa secara individu dapat mengembangkan aktivitas belajar mandiri, mengikuti arahan instruksi tugas yang dirancang secara bertahap dan sistemik. Siswa dapat belajar memahami fenomena alam atau menganalisis isu-isu sosial dan nilai-nilai budaya secara bertahap sesuai perkembangan jenjang pendidikannya di sekolah. Kondisi seperti ini dapat membangun inisiatif-inisiatif belajar siswa dengan memanfaatkan berbagai sumber, meningkatkan produktivitas belajar 
individu, meningkatkan kreativitas memecahkan masalah.

Rancangan kegiatan belajar berpusat pada siswa, dengan peran guru, administrator sekolah, orangtua dan masyarakat sebagai fasilitator. Setiap tahapan kegiatan dirancang berpusat pada siswa baik secara individu maupun kelompok. Aktivitas siswa dapat bervariasi, diantaranya adalah pengamatan dan diskusi yang terbagi dua tahap, selanjutnya pengkajian pustaka dan yang terakhir adalah pemaparan hasil. Pengamatan bertujuan memberikan penguatan terhadap pengalaman atau pengetahuan yang telah dimiliki ataupun pengamatan untuk inkuiri yang berhubungan dengan materi (informasi, fenomena, isu) pembelajaran baru, dan diskusi untuk mengidentifikasi masalah dan faktor penyebab masalah. Diskusi tahap ini siswa diarahkan untuk menganalisis hubungan antara fakta-fakta di lingkungan sekitar dengan konsep-konsep terkait dalam matapelajaran. Identifikasi masalah juga dapat diperkuat dengan menyiapkan informasi, fenomena atau isu-isu relevan yang ada di tempat lain atau global. Or angtua dan masyarakat dapat berperan sebagai narasumber dalam diskusi. Diskusi ini lebih strategis kalau dilakukan di luar sekolah. Kegiatan diskusi selanjutnya adalah merumuskan kesimpulan hasil pengamatan dan analisis isu dan fenomena. Diskusi ini dapat meliputi diskusi dalam kelompok kegiatan belajar atau lintas kelompok. Diskusi lintas kelompok dapat dilakukan untuk kegiatan yang sama yang dilaksanakan oleh masing-masing kelompok atau diskusi kegiatan yang berbeda namun berada dalam topik atau tema yang sama. Pengkajian pustaka dilakukan siswa untuk mene.lusuri konsepkonsep dalam instruksi tematik. Kegiatan ini bersifat reviu terhadap konsep-konsep yang telah dipelajari sebelumnya atau untuk mendapatkan penjelasan/ penguatan terhadap kesimpulan hasil pengamatan dan analisis masalah. Terakhir adalah pemaparan hasil pengamatan, analisis masalah, dan kajian pustaka, baik dilakukan secara individual maupun kelompok.

Materi tugas tematik bersifat multisumber. Walaupun penekanan materi tugas tematik adalah fenomena alam, isuisu social, dan nilai- nilai kultural yang ada di sekitar siswa, namun materi tugas tematik juga mencakup informasiinformasi, fenomena, isu-isu global (atau yang ada di tempat lain) yang memiliki keterkaitan atau relevansi substansial dengan materi lokal. Pemanfaatan sumber lokal ditujukan untuk menjamin kesesuaian materi pembelajaran dengan pengalaman siswa, merumuskan variasi-variasi kegiatan yang menyenangkan siswa dan membangun insiatif-inisiatif belajar siswa karena tuntutan lingkungan sekitar (siswa lain termasuk yang berbeda jenjang, orangtua, masyarakat dan sekolah). Pemanfaatan sumber materi tugas dari luar sekolah dan global bertujuan untuk membangun pengalaman dan pengetahuan komparatif. Pengalaman dan pengetahuan komparatif siswa memberi penguatan dan pengayaan (variasi masalah, fenomena, isuisu) yang memiliki kesamaan konseptual.

Pentingnya keterlibatan siswa dalam perancangan materi antara lain bermanfaat untuk mengetahui: keinginan individu terhadap materi dan variasinya untuk perumusan alternatif-alternatif kegiatan kelompok atau individu sehingga instruksi tugas tematik akan menyenangkan, menarik sekaligus menantang bagi siswa; dan berapa banyak pengalaman yang dimiliki siswa untuk penetapan materi pembuka atau konsep-konsep yang perlu direviu oleh guru, sehingga siswa atau kelompok siswa dapat melaksanakan instruksi secara mandiri.

Menurut Kunandar yang dikutip oleh Mustofa (2015), pembelajaran tematik memiliki beberapa kelebihan yaitu :

1. Menyenangkan karena berangkat dari minat dan kebutuhan peserta didik.

2. Memberikan pengalaman dan kegiatan belajar mengajar yang relevan dengan tingkat perkembangan dan kebutuhan peserta didik. 
3. Hasil belajar dapat bertahan lama karena lebih berkesan dan bermakna.

4. Mengembangkan keterampilan berfikir anak didik sesuai dengan persoalan yang dihadapi.

5. Menumbuhkan keterampilan sosial melalui kerja sama.

6. Memiliki sikap toleransi komunikasi dan tanggap terhadap gagasan orang lain.

7. Menyajikan kegiatan yang bersifat nyata sesuai dengan persoalan yang dihadapi dalam lingkungan peserta didik.

Anonymous (2004) mengemukakan beberapa hal penting yang berkaitan dengan pembelajaran demokratik seperti: guru dan siswa bekerja bersama untuk membuat pembelajaran siswa menjadi kontribusi bagi komunitas tempat mereka tinggal; siswa bekerja aktif dengan menyelesaikan masalah yang diberikan melalui tugas yang telah disiapkan oleh guru.

Pemberian tugas berbeda dengan pekerjaan rumah. Roestiyah yang dikutip oleh Kusumah (2012), menjelaskan perbedaaan antara pekerjaan rumah dan pemberian tugas: "Untuk pekerjaan rumah, guru menyuruh membaca dari buku dirumah, dua hari lagi memberikan pertanyaan dikelas. Tetapi dalam pemberian tugas guru menyuruh membaca dan mencari buku lain untuk membedakan atau membandingkan". Kembali Roestiyah yang dikutip oleh Kusumah (2012) menulis bahwa teknik pemberian tugas memiliki tujuan agar siswa menghasilkan hasil belajar yang lebih mantap, karena siswa melaksanakan latihan-latihan selama melakukan tugas, sehingga pengalaman siswa dalam mempelajari sesuatu menjadi lebih terintegrasi.

Garfield (1994) menulis bahwa pemberian tugas harus meningkatkan pembelajaran. Melalui tugas yang telah diberikan kepada siswa untuk mengobservasi masalah dilapangan, pengetahuan siswa akan bertambah.

Orangtua dan masyarakat merupakan komponen penting untuk suskesnya pendidikan anak di sekolah. Burhanuddin (2013) menulis hubungan antara sekolah dan masyarakat:
1. Sekolah adalah bagian yang integral dari masyarakat; bukan merupakan lembaga yang terpisah dari masyarakat.

2. Hak hidup dan kelangsungan hidup sekolah bergantung pada masyarakat.

3. Sekolah adalah lembaga sosial yang berfungsi untuk melayani anggota-anggota masyarakat dalam bidang pendidikan.

4. Kemajuan sekolah dan kemajuan masyarakat saling berkorelasi; keduanya saling membutuhkan.

5. Masyarakat adalah pemilik sekolah; sekolah ada karena masyarakat memerlukannya.

Salwinsah (2011) menuliskan beberapa cara yang bisa dilakukan orangtua dalam membantu pendidikan anak: mengontrol waktu belajar dan cara belajar anak, memantau perkembangan kemampuan akademik anak, dan memantau efektifitas jam belajar di sekolah. Setiabudi (2012) mengemukakan beberapa kewajiban orangtua dalam proses pembelajaran anak yaitu: membuat belajar itu mengasyikkan, menjadi pendamping belajar yang efektif, dan memiliki sasaran sukses. Keberhasilan mencapai sasaran-sasaran akan membuat sang anak makin bersemangat.

\section{METODE PENELITIAN}

Penelitian ini bertujuan untuk mendeskripsikan hubungan konsep fisika dengan konsep matapelajaran lain dan konteks siklus air berdasarkan capaian penguasaan konsep dan kemampuan mengidentifikasi masalah dilapangan.

Metode penelitian yang akan digunakan adalah korelasi. Khansa (2011) menjelaskan bahwa dalam penelitian jenis ini, peneliti berusaha menghubungkan suatu variabel dengan variabel yang lain untuk memahami suatu fenomena dengan cara menentukan tingkat atau derajat hubungan di antara variabel-variabel tersebut. Tingkat hubungan tersebut ditunjukkan oleh nilai koefisien korelasi yang berfungsi sebagai alat untuk membandingkan variabilitas hasil pengukuran terhadap variabel-variabel tersebut. Sudijono (2011) menuliskan bahwa untuk mencari korelasi antara skor-skor hasil tes pertama dengan skor-skor hasil tes kedua, dipergunakan teknik teknik korelasi tata jenjang dari Spearman.

Barhanudin yang dikutip oleh Sarwono (2006) menyatakan bahwa koefesien korelasi 
menunjukkan kekuatan (strength) hubungan linear dan arah hubungan dua variabel acak. Jika koefisien korelasi yang di dapat positif, maka kedua variabel dikatakan memiliki hubungan searah. Hal ini berarti jika nilai variabel $\mathrm{X}$ tinggi, maka nilai variabel $\mathrm{Y}$ akan tinggi pula. Sebaliknya, kedua variabel dikatakan memiliki hubungan terbalik jika koefesien korelasi negatif. Artinya jika nilai variabel $\mathrm{X}$ tinggi, maka nilai variabel $\mathrm{Y}$ akan menjadi rendah dan sebaliknya. Kembali Barhanudin dikutip oleh Sarwono (2006), menulis kriteria untuk memudahkan melakukan interpretasi, yaitu sebagai berikut:

Tabel 1. Kriteria Interpretasi Korelasi

\begin{tabular}{cl}
\hline $\begin{array}{c}\text { Koefisien } \\
\text { Korelasi }\end{array}$ & \multicolumn{1}{c}{ Kriteria } \\
\hline 0 & $\begin{array}{l}\text { Tidak ada korelasi antara } \\
\text { dua variabel }\end{array}$ \\
\hline$>0-0,25$ & Korelasi Sangat lemah \\
\hline$>0,25-0,5$ & Korelasi Cukup \\
\hline$>0,5-0,75$ & Korelasi kuat \\
\hline$>0,75-0,99$ & Korelasi Sangat Kuat \\
\hline 1 & Korelasi Sempurna \\
\hline
\end{tabular}

\section{HASIL DAN PEMBAHASAN}

\section{Hasil Penelitian}

1. Hubungan (korelasi) penguasaan konsep fisika perubahan wujud zat dengan konsep biologi evapotranspirasi dari 8 siswa adalah 0,59 dan sesuai tabel, hasil ini di kategorikan memiliki korelasi kuat.

2. Hubungan (korelasi) observasi lapangan mengidentifikasi limbah (padat dan cair) di sungai dengan teknologi pengolahan limbah dan bentuk pengendalian pencemaran air adalah 1, hasil ini di kategorikan memiliki korelasi sempurna.

3. Hubungan (korelasi) kemampuan siswa mengidentifikasi sumber-sumber air di desa, desa tetangga dan di tempat lain dengan penguasaan konsep skema siklus air dengan komponenkomponennya menuliskan dibagian mana air dimanfaatkan di desa adalah 0,89, hasil ini dikategorikan memiliki korelasi sangat kuat.

\section{Pembahasan}

Hasil korelasi penguasaan konsep fisika perubahan wujud zat dengan konsep biologi evapotranspirasi dari 8 siswa kategorikan memiliki korelasi kuat sesuai dengan tabel nilai koefisien korelasi Spearman Rank. Evapotranspirasi sebenarnya adalah gabungan dari dua komponen penting dalam siklus air, yaitu evaporasi dan transpirasi. Evaporasi dan transpirasi merupakan proses penguapan, yaitu berubahnya air menjadi uap air dimana evaporasi adalah air yang hilang ke atmosfir dari permukaan air seperti kolam, danau, sungai ataupun laut yang berasal dari air bawah tanah; sedangkan transpirasi adalah air yang hilang ke atmosfir dari tumbuhan yang melalui akar menyerap air dari air bawah tanah. Sehingga tidaklah mengherankan jika kedua indikator ini memiliki hubungan atau korelasi kuat.

Hasil korelasi observasi lapangan mengidentifikasi limbah (padat dan cair) di sungai dengan teknologi pengolahan limbah dan bentuk pengendalian pencemaran air memiliki korelasi sempurna sesuai dengan tabel koefisien korelasi Spearman Rank. Dilapangan, siswa mengidentifikasi limbah yang dibuang di sungai baik limbah padat maupun limbah cair kemudian pergi ke rumah masyarakat untuk bertanya dampak dari pencemaran air oleh limbah disungai. Dasar pengetahuan melalui pengalaman tersebut membuat siswa mampu mengerjakan tugas tentang bagaimana mengolah limbah dan mengendalikan pencemaran air.

Hasil korelasi konsep skema siklus air dengan komponen-komponennya dengan kemampuan siswa mengidentifikasi sumber-sumber air di desa, desa tetangga dan di tempat lain menurut tabel koefisien korelasi Spearman Rank hasil yang di dapat termasuk dalam kategori korelasi sangat kuat. Eberbach \& Crowley dalam Kelly (2013) menulis, melalui proses observasi, kemampuan siswa berkembang untuk menyusun pertanyaan yang tepat, merekam dengan akurat data-data relevan yang didapat dan menarik kesimpulan dari hasil observasi tersebut. Saat mengidentifikasi sumber-sumber air di desa, desa tetangga dan tempat lain, siswa berdiskusi dengan orangtua dan masyarakat 
sampai mereka benar-benar tahu sumbersumber air yang digunakan masyarakat khususnya yang di manfaatkan desa mereka sendiri. Hal ini menyebabkan siswa bisa menguasai konsep siklus air dan khususnya bisa menggambarkan skema siklus air di desa sendiri dan menuliskan dibagian mana air di manfaatkan didesa.

\section{KESIMPULAN}

Berdasarkan hasil penelitian dapat disimpulkan bahwa pembelajaran berbasis tugas tematik dapat membangun pemahaman siswa tentang hubungan dari komponenkomponen dalam siklus air di lingkungan sekitar dengan konsep-konsep fisika yang dipelajari di dalam kelas dan hubungan konsep antar bidang studi.

\section{REFERENSI}

Anonymous. 2004. Democratic Learning- The League of Professional School. The University of Georgia. Di akses 9 Mei 2016 dari http://www.leagueschools.com/dem_logic .pdf.html

Burhanuddin, Afid. 2013. Pengelolaan Partisipasi Masyarakat Dalam Pendidikan. Di akses 4 Februari 2016 dari https://afidburhanuddin. wordpress.com/2013/12/26/pengelolaanpartisipasi-masyarakat-dalam-pendidikan/

Garfield, Joan B. 1994. Beyond Testing and Grading: Using Assesment to Improve Student Learning. Journal of Statistics Education. (Online), v.2 n. Di akses 28 April 2016 dari http://www.amstat.org

Kelly, K. M. 2013. Science Journals in the Garden: Developing the Skill of Observation in Elementary Age Students. Thesis. Portland: Portland State University Graduate Program.

Khansa, Mana. 2011. Penelitian Korelasional. Di akses 4 Februari 2020 dari https:// amanahtp.wordpress.com/2011/11/24/pen elitian-korelasional/

Kusumah, Wijaya. 2012. Apakah Metode Pemberian Tugas Itu. Di akses 4 Februari 2020 dari http://guraru.org/guruberbagi/apakah _metode_pemberian_tugas_itu/

Medellu, Chris. 2013. Thematic Assignment Basic Mode. Di akses 4 Februari 2019 dari http://chrismedellu.wordpress.com/2013/0 3/13/thematic-assignment-basic-model/

Melayu, Jamaris. 2014. Pembelajaran Tematik

Tingkat Terpadu. Di akses 4 Februari 2019

dari

http://www.jamarismelayu.com/2014/09/

pembelajaran-tematik-terpadu-

tingkat.html

Mitchell, H. H, dkk. 1945. The Chemical Composition of The Adult Human Body and Its Bearing on The Biochemistry of Growth 625-637. Di akses 5 Juni 2019 dari http://www.jbc.org/content/158/3/625.cita tion

Mustofa, Sahli. 2015. Kelebihan dan Kelemahan Pembelajaran Tematik. Di akses 4 Februari 2019 dari http://www.mbahtopa. com/2015/06/kelebihan-dan-kelemahanpembelajaran. html

Salwinsah. 2011. Peranan Orangtua, Sekolah dan Guru dalam Mensukseskan Pendidikan. Di akses 12 Juli 2019 http://salwintt.wordpress.com/artikel/1092/peranan-orangtua-sekolah-dan-gurudalam-mensukseskan-pendidikan/

Sarwono, Jonathan. 2006. Metode Penelitian. Yogyakarta : Graha Ilmu.

Setiabudi, Tessie. 2012. Peran Orangtua dalam Belajar-Mengajar. Di akses 4 juli 2019 http://kesehatan.kompasiana.com/ibudan-anak/2012/12/10/peran-orang-tuadalam-belajar-mengajar-514736.html

Sudijono, Anas. 2011. Pengantar Evaluasi Pendidikan. Jakarta : PT Raja Grafindo Persada.

United States Geological Survey. 2019. The Water Cycle Di akses 28 April 2019 dari http://ga.water.usgs.gov /edu/watercycle.html

United States Geological Survey. 2019. The Water Cycle: Evapotranspiration. Di akses $28 \quad$ April 2019 dari http://water.usgs.gov/edu/ watercycleevapotranspiration.html

Widiyanto, Mikha A, 2013. Statistika Terapan. Jakarta: Elex Media Komputindo

Wikipedia. 2019. Thematic learning. Di akses $28 \quad$ April $2019 \quad$ dari https://en.wikipedia.org/ wiki/Thematic_Learning 